ESJ Humanities

\title{
Common Property: English as a Lingua Franca in Ghana, The Perspective of the College of Education Tutor
}

\author{
Donkor, $G$. \\ Wesley College of Education, Ghana \\ Lomotey, C.F., PhD \\ University of Education, Winneba, Ghana
}

Doi:10.19044/esj.2021.v17n36p146

Submitted: 15 September 2021

Accepted: 06 October 2021

Published: 31 October 2021
Copyright 2021 Author(s)

Under Creative Commons BY-NC-ND

4.0 OPEN ACCESS

Cite As:

Donkor, G. \& Lomotey, C.F. (2021). Common Property: English as a Lingua Franca in Ghana, The Perspective of the College of Education Tutor. European Scientific Journal, ESJ, 17 (36), 146. https://doi.org/10.19044/esj.2021.v17n36p146

\begin{abstract}
The study sought to investigate English as a Lingua Franca (ELF) in the classroom of the College of Education tutor in Ghana using the Ashanti Region as a case. A total of 48 participants were selected from 9 Colleges of Education for the study using purposive sampling. Data were collected using a six-point Likert-type scale questionnaire and a semi-structured interview guide. Data analysis and presentation of results were done using mean and standard deviations. The study revealed that intercultural awareness was important for language users. These findings could be interpreted as the changing conceptualizations of English language and pedagogy among language tutors in various contexts. Tutors' awareness of the need to communicate in English was not restricted to native speaker communities. It was recommended that tutors should seek ways of acquiring attitudes that can help them create a congenial atmosphere for teaching and learning as/ this is needed by students to understand what their tutors teach them.
\end{abstract}

Keywords: ELF-aware, CoE, Tutors, Native Speakers, English, Variety

\section{Introduction}

English as a lingua franca has gained a lot of recognition over the years due to the proliferation of English by non-native English speakers. English, also used as a "practical tool" and often as a "working language" (Crystal, 
2003, p.426), has arisen as a lingua franca used by millions of people to participate in conversations with each other. Today, we live in an integrated globalized environment (a global village) where the number of non-native English speakers exceeds the number of native speakers (Crystal, 2003, p.426). Seidlhofer (2012) observed that, by necessity, the lingua franca does not have native speakers, but that all of its speakers must learn to use it. In describing what ELF is, Firth (1996) describes it as a communication language between individuals who do not share either a shared natural language or a common national culture. ELF analysis is not uncontentious and has been blamed for being conceptually and technically underdeveloped. Contrary to Baker and Jenkins (2015) statement of a consensus over ELF theories as a use of English rather than a possible variety of English, Mortensen (2013) argued that ELF is "often implicitly conceptualized as a bounded object, a particular 'language system' with its own 'characteristic' lexicogrammatical and pragmatic features" (p. 35).

The history of English in Ghana, in particular the initial interaction between the British and the people of Ghana in the 16th century, tells the story of the advent of English as a language of commerce, schooling, government and as a cross-ethnic lingua franca (Adjaye, 2005; Boadi, 1994; Sackey, 1997; Sey, 1973). Sackey (1997) noted that some of these English schools, particularly those in Cape Coast, had survived colonial times due to the extraordinary effort of Philip Quaicoe, who taught his students reading, writing, and learning the Bible. Colonial and missionary language policies have also led to the consolidation of English in the region. Sey (1973), in his groundbreaking dissertation on and through the course of time in Ghanaian English, has experienced tremendous shifts in the history and sociology of Ghana, as well as in the global climate. There is a distinctive Ghanaian variation of English, the point of which was unquestionably expressed by Quarcoo (1994). Beyond morphology and syntax (which are often cited as fields of deviant use), the pragmatic use of English (for example, modes of application) is a clear direction in which non-native varieties can hold sway (Anderson, 2006; Dzameshie, 2001; Keleve, 1995).

It is worth mentioning that the linguistic standard has shifted and that English no longer belongs to a popular variety that has distinctive features at all linguistic stages (phonological, syntactical, lexical and semantics). It is actually a scenario composed of a wide variety of self-evolving varieties used in diverse sociolinguistic environments that are juxtaposed rather than subordinated. As Canagarajah (2005, p. xxiii) points out, "English has gained a life beyond its land of origin, acquiring identity and currency in new geographical and social domains as it is localized for a variety of purposes." Early differences between English varieties worldwide have been codified by Quirk et al (1972), who defined three types of English varieties: varieties in 
which English is spoken as a natural language, varieties in which English is spoken as an additional language, and varieties in which English is spoken as a foreign language. The framework of Quirk et al is specifically based on the generalization of cultures and their socio-political systems, including the official language of the region and its language policy and language education system. Generalization is an important, conclusive aspect of theoretical construction; in order to create an overall structure for the representation of several variables and functions. Kirkpatrick(2006) postulates that, because of the historical authority possessed by some varieties, people prefer to argue for their innate dominance as linguistic templates over newly formed varieties. This process of reasoning is technically known as the Imposed Standard or Context-driven Theory (Giles et al, 1974).

The distinguishing characteristic of the ELF is its linguistic, pragmatic and cultural versatility as a medium of communication that is suitable for particular interlocutors under unique communicative circumstances (Jenkins, 2015; Mauranen, 2012; Seidlhofer, 2011). The emphasis is therefore not so much on language itself, but on the sense of ELF contact and users, the "community rather than the code" (Kalocsai, 2014, p.2) and the "discourse communities with a common communicative purpose" (Seidlhofer, 2011, p.87). This poses fascinating observations as to what people do with English when they talk, and includes an understanding of the "unusually complex contact" situations (Mauranen 2012, p.29) between English and the other languages involved that make ELF a second-order language contact or a "hybrid of similarities" (Mauranen, 2012, p.30). ELF scholars found ELF to be culturally neutral (Meierkord, 2002); a flexible instrument for communicating in intercultural settings, but definitely not a language for recognition (House, 1999, 2003). Early conceptualizations regarded ELF as, for example, "a 'contact language' between persons who do not share a common native language or a common (national) culture, and for whom English is the chosen foreign language of communication" (Firth, 1996, p. 240) and as existing only in 'interactions between members of two or more distinct linguistic communities in English, for none of whom (House, 1999, p. 74). These definitions explicitly omitted native English speakers from the ELF, although this difference is not found in later definitions.

A core form of this dimension of ELF awareness is awareness of teacher-related experience, which revolves around what tutors do (and do not do) in the classroom, including their own teaching philosophies, corrective guidance (Lyster \& Saito, 2010) and measuring and reacting to learners' needs. Again, beliefs and attitudes regarding the notion of error (Long, 1991) and its origins (i.e. L1 transition, omission and over-generalization or simplification of L2 rules (Ellis, 2010 ) are key considerations, as is the role of tutors as viewed and encountered by themselves and other stakeholders in their local 
context (Sifakis, 2009). Other types of educational practice understanding are textbook-and policy-related. All of these types require an understanding of the degree to which the educational situation is directed towards a particular target (e.g. completing a high-stakes exam) and whether learning materials and instructional activities prioritize a norm-bound approach (Sifakis, 2004).

\section{ELF Awareness in ESL classroom}

The sociolinguistic background of language education covers both the educational atmosphere within the classroom and the broader social landscape outside the classroom. Pennycook (2001) criticizes the fact that language teaching is mostly practiced in schools as distinct from the broader outside world. From the point of view of applied linguists, assisting students in studying English presupposes that the topic of learning in educational settings must represent the entity being observed on how it functions as a sociolinguistic phenomenon (Leung, 2013; McKay, 2000; Seidlhofer, 2011; Wang, 2015; Widdowson, 2003). It's not hard to realize that the understanding of what's going on in the use of English in the real-life world can better train students in the classroom for their future English-medium experiences in the classroom. It merits deliberation, though, where the emphasis can be on the wider social universe. Provided that ELF is a recently defined concept in the broader social world, linguists (Cogo \& Dewey, 2012; Jenkins, 2007; Mauranen \& Ranta, 2009) have warned of the difference between what is learned in the classroom and what is happening outside the classroom.

It is therefore high time that we explored the degree to which the ELF hypothesis is realized and expressed in learning settings in order, if it exists, to explore solutions to the void. The subject matter concerns the understanding of "English" in English education. The creation of ELF science has called for the restoration of "the thing that is called English" (Seidlhofer, 2011, p. 1). In this way, the conventional approach to English, which resembles the handling of languages as discreet linguistic structures, has become outdated. ELF study contributes to the perception of English as functional, changing, flexible, and multilingual (Baker, 2015; Cogo \& Dewey, 2012; Jenkins, 2015a; Mauranen, 2012; Seidlhofer, 2011). Research also reveals that ELF users do not wish to join the native English-speaking community but are interested in becoming global citizens (Jenkins, 2007; Wang, 2012). Thus, although the conventional approach to second-language learning is native English-oriented, changes are required to re-approach second-language learners in response to the sociolinguistic development of the ELF.

\section{Challenges for ELF-aware Teacher}

The concepts underpinning this multilingual approach to Englishlanguage learning are aimed at improving intercultural communication skills 
for learners (Kohn, 2015; Kramsch, 2009), assessing and strengthening their multilingual vocabulary (Mauranen, 2012; Seildhofer, 2011), as well as encouraging the ability of learners to speak and translate (Canagarajah, 2011, 2013; Blommaert, 2010; Swain, 2006), and , in order to do this, the teacher could be faced with the following obstacles in the ELF classroom:

Tutors' apparently innate aversion to change: understanding ELF and introducing ELF-aware teaching are two things. This suggests the tutors may understand ELF but may not be ready or able to incorporate it in their context. This may be attributed to inherent confidence in the undisputed utility of Standard English (Suzuki, 2011). This is where the ELF-aware approach can be helpful in that it does not dictate a particular way of educating ELF but relies on social awareness and teacher freedom.

Tutors' own views of their positions in the ELF classroom: how tutors see themselves and their jobs and are perceived by colleagues can be a powerful barrier to ELF-conscious instruction. It poses important problems that also concern morals. For example, topics such as how ethical it is to be ELF-aware, the degree to which it is 'right' or 'wrong' for those concerned, and the ultimate obligation to interfere with the defined curriculum, chosen textbooks and stated directions. However, recognizing that ELF-aware instruction is not either/or a case, but adding to the current arsenal of tutors means that tutors do not have to teach ELF, they will give their learners more options.

Learners' and other stakeholders' viewpoints and expectations: a wider sense, including articulated and secret learning goals for English, and sponsors' (parents, companies) perspectives on what is expected and thus 'required' in the ESOL classroom. This, along with a long tradition of pedagogy focused on traditions that assign preference to native-speaking standards, creates an 'ecosystem' of existing culture that is not inherently conducive to ELF-conscious teaching and learning (Sifakis, 2009).

Trends in curricular creativity and textbook-centered mentality: Since more traditional EFL environments concentrate on training students for high-stakes tests, their curriculum appear to be largely standard-referenced and textbook-centered, and this typically adversely impacts teaching and learning (Wall, 2005). Even as the current curriculum prioritizes, in theory, at least multiculturalism and the function of English for global and cosmopolitan citizenship, the textbooks do not follow suit (Sifakis et al, 2012; Song, 2013). These procedures make it especially challenging for those tutors who serve in prep schools who wish to incorporate ELF-aware practices into their classrooms. ELF-aware training and teaching create resources for learning about ELF and playing with one's teaching background, which helps tutors to make sense of changing times in English. This also encourages them to 
discover modern, innovative and independent ways of incorporating ELF into their own context.

Being an ELF-aware instructor involves seeking ways to inspire one's learners as capable non-native English-speaking users, effectively prompting them to become ELF-aware users themselves. The ecological emphasis and ultimately disruptive essence of the ELF-aware journey has ramifications beyond teaching and learning that can be extended to evaluation and research, policy-making and curriculum design. As such, more research should be done on ELF-aware applications in various teaching-learning environments to record (a) the level of meaningful thinking that different tutors are capable of and ready to participate in, and (b) the consistency and true effect of ELFaware practices and classes. It is therefore important to build a way of calculating (a) and (b) and thus help ELF-aware teaching research to take a shape that would be more suitable for the use of the ELF-construction (with all its fluidity) in the classroom. These implementations will ultimately decide the degree to which ELF is truly teachable or whether the only practical way to incorporate ELF in a foreign language classroom is by ELF-awareness. After all, to mirror Elbert Green Hubbard's popular concept of art, ELF is not a feature, it's a way.

ELF transcends borders and allows for continuous variables, which is the product of the context of the consumer, both linguistic and socio-cultural, which affects their performance. While in the works of Jenkins (2000), Breiteneder (2005) or Dewey (2006), certain repeated ELF regularities have been found, they have not resulted in ELF being a codified variety and are still far from being regarded as normal. However, it suggests that there are several recommendations about the incorporation of some elements of the ELF into the teaching programmes (Lopriore, 2016). These will involve raising the consciousness of English tutors and ELF tutors. Elements that are already accepted as prevailing in the sense of the lingua franca. If English tutors know that tactics prevail, they will help their students to cope with the evolving atmosphere in which English is used worldwide, in line with the students' own communication needs in the lingua franca sense.

ELF-aware tutors in Ghanaian Colleges of Education are creating a view of English as a lingua franca that will have an effect on them. With their mindset towards the English language and how to present the language to learners in their pedagogical tasks and practices, a modern vision of language will be turned into a new method of teaching. However, shifting teacher perceptions to the point of accepting the concept of ELF and questioning existing norms and values regarding the importance of a traditional native language variety is a complicated process that will not happen by merely reminding tutors of the presence of ELF. 


\section{The study}

The idea of ELF knowledge is meant to act as an understanding of the role of tutors and learners, as well as other members of the ELT (e.g. decisionmakers, curricula creators, textbook creators, evaluators and testers) in this building. The benefits of binding ELF to the English Language Teaching (ELT) classroom derive from the idea that English Language Learners are effective users of English in their own right. CoE English tutors continue to set unachievable targets, use unfriendly courseware and a conventional ELT approach. Students have to suffer excessively, not because they are linguistically handicapped or unintelligible, but because they are not taken into account in the preparation of the program and because their needs are not fulfilled. The English language is changing and the emphasis on English in the classroom has shifted. The CoE English tutors are not aware of the update. There is also a need to increase awareness about these improvements. The role of the ELF is a valid ingredient in the learning experience of learners. It has become clear that ELF has consequences for ELT classrooms, and this allows tutors to objectively focus on ELF, which is why this research aims to examine the understanding of ELF among tutors at the College of Education in Ghana. It is believed by the authors that ELF users must contend with a high degree of unpredictability in terms of oral contact due to the emerging fluid and existence of ELF. That is why there the need for these tutors to be aware of ELF and the ELF model

\section{Methodology \\ Participants}

Forty-eight English tutors (31 female, 17 male) participated in the study. All of the participating tutors were instructors in the English language from Agogo Presbyterian College of Education, Agona SDA College of Education, Akrokerri College of Education, Mampong Technical College of Education, Offinso College of Education, Wesley College of Education, St. Monica's College of Education, St. Louis College of Education and Christ the Teacher College of Education. Findings of the background questionnaire indicated that twenty-five tutors had taught for over ten (10) years while fifteen had taught for between 5 and 10 years and eight had been teaching for less than five years.

\section{Data Collection}

Data were collected from respondents using a questionnaire. The questionnaire had a number of statements that elicited information on demographic information and variables that determined participants' ELF Awareness. The questionnaire comprises two parts. Items in the first part tap the knowledge of tutors on ELF and tutors' beliefs regarding ownership and 
use of English. Items in the second part, tap tutors' awareness of ELF and whether it informs their teaching practice. For the intelligibility and reliability concerns, the questions were checked by three experts in the field. The reliability of the questionnaire was measured after a piloting study with 10 English tutors. 5 of the participants of the pilot study and two experts in the field were interviewed to learn their ideas about the intelligibility of the items in this section. As a result of reliability measurement, the overall Cronbach's alpha result was found to be .86 which is high enough to administer the questionnaire. After the administration of the questionnaire, the overall reliability was calculated again and found to be .79 .

\section{Data Analysis}

Descriptive statistics (mean and standard deviation) were used for the analysis of the questionnaire data. The means and standard deviations were deemed to be appropriate because the import of the research was to weigh the views of the participants. According to Michael (2013), the standard deviation is used in conjunction with the mean to summarize continuous data, not categorical data. In addition, the standard deviation, like the mean, is appropriate when the continuous data are not significantly skewed or has outliers.

\section{Results}

When asked about the understanding of the ELF model, all participants replied that they needed some linguistic and pedagogical knowledge and skills that would allow them to encourage foreign intelligibility in their classrooms.

Table 1: Tutors awareness of ELF Model

\begin{tabular}{lccc}
\hline Statement & $\begin{array}{c}\text { Mean } \\
\text { S }\end{array}$ & $\begin{array}{c}\text { Std. } \\
\text { Dev }\end{array}$ & rank \\
\hline I localize English to suit the context in which I teach & 2.85 & .65 & 3rd \\
I allow my students to express themselves freely in class & 2.41 & .80 & 5 th \\
I am conscious of the need to develop in my learners the & & & \\
capacity to communicate intelligibly with each other & 3.13 & .89 & 1 st \\
despite the inevitable existence of errors & & & \\
I motivate my students to have self-confidence & 2.44 & 1.09 & 4th \\
I sometimes deviate from the existing curriculum & 2.88 & 1.06 & 2nd \\
\hline
\end{tabular}

Rank order on why the need for College of Education tutor to be aware of ELF and ELF model presented in Table 8 show that the consciousness of the need to develop learners capacity to communicate intelligibly is $1^{\text {st }}(\mathrm{M}=$ 3.13; $\mathrm{SD}=.89)$, deviation from the existing curriculum is $2^{\text {nd }}(\mathrm{M}=2.88 ; \mathrm{SD}=$ $1.06)$, and localization of the English to suit a context of teaching places $3^{\text {rd }}$ $(\mathrm{M}=2.85 ; \mathrm{SD}=0.65)$ are the most prevalent of all the variables that contribute to tutors awareness of the ELF model. Among the reasons provided by them, 
the context was indicated as the most common source of miscommunication, with the participants stating:

... you see, language is about context...so I always try to localize English to suit out context...I think the students love it...they are doing well....we are getting there(ETR 4)

...I think going forward I need to design my own activities to suit my learners and our Ghanaian context...I it it's the way to go.... the students must be able to relate the content and practicalize in their own context (ETR 1)

most of our colleagues think they are going to teach themselves....sat in friend's lesson and I pitied the students...how can they understand?... when we understand the concept of ELF well we will prepare our lessons with my learners needs in mind .... (ETR 2)

the problem I have with the foreign courseware is that they were to suit their context....the conditions are different.... when we as tutors even meet we speak twi how more the students?....Most of them read some of the foreign textbooks and they can't even relate.....you and I know that Learners learn better when local courseware is used (ETR 3)

As a result, tutors need to build a framework for assessing ELF-aware lesson plans, individual lessons and self-assessment of these lessons, taking into account both ELF-related concepts and local teaching and learning environments. What was very surprising about the responses given was that the participants appeared to be well conscious of their own talents and lack of them. They said they were scared to make a mistake, they did not want to joke about it. That may be attributed to the fact that they are actually uncertain in terms of their own abilities, which they measure against the regular English language, if their efforts are successful, the meaning is conveyed, grasped and acted upon, but rather whether they were grammatically right in doing so. 
Table 2: The need for ELF awareness for CoE Tutors

\begin{tabular}{lccc}
\hline Statement & Means & Std. Dev & rank \\
\hline $\begin{array}{l}\text { I need ELF awareness to understand what tutors } \\
\text { should do and should not do in the English classroom }\end{array}$ & 2.24 & 1.06 & 5 th \\
$\begin{array}{l}\text { I need ELF awareness to be able to give corrective } \\
\text { feedback to my learners }\end{array}$ & 2.19 & .96 & 6th \\
$\begin{array}{l}\text { I need ELF awareness to be able to respond to } \\
\text { learners needs }\end{array}$ & 2.04 & 1.01 & 7 th \\
$\begin{array}{l}\text { I need ELF awareness to understand learners errors } \\
\text { and their sources }\end{array}$ & 2.90 & .91 & 1st \\
$\begin{array}{l}\text { I need ELF awareness to understand so that I can treat } \\
\text { my own non- native English spoken discourse as a } \\
\text { viable model my learners can aspire to and help them } \\
\text { become more confident }\end{array}$ & 2.87 & .87 & 2nd \\
$\begin{array}{l}\text { I need ELF awareness so that I do not intervene to } \\
\text { correct my learner's oral communicative activities } \\
\text { that do not hinder comprehensibility }\end{array}$ & 2.80 & .81 & 3rd \\
$\begin{array}{l}\text { I need ELF awareness to be able to put my personal } \\
\text { theories about instruction aside }\end{array}$ & 2.78 & .88 & 4th \\
\hline
\end{tabular}

In responding to the statement, "The need for ELF awareness for CoE Tutors" all the respondents were very emphatic in their answers. Thirty-Seven (37) participants $(77.1 \%)$ were in the affirmative and eleven respondents $(22.9 \%)$ were of a neutral view. When reasons were sought for the responses, those who were affirmative were of the opinion that they need ELF awareness to understand what tutors should do and should not do in the English classroom; need ELF awareness to understand learners errors and its sources; need ELF awareness so that they do not intervene to correct learners oral communicative activities that do not hinder comprehensibility; and need ELF awareness to be able to put personal theories about instruction aside.

The activities on building an ELF skillset is useful and varied. Awareness-raising of borrowing vocabulary from L1 is a useful suggestion. There are activities that raise awareness of common features of ELF interactions like complement ellipsis, and there are others that encourage learners to question whether certain grammatical variations should be deemed incorrect. However, there are some that, with all the best intentions, take the idea of ELF too far. It is certainly useful to promote an ELF mindset to learners if they are likely to critically engage in the topic, but we are talking about time in the classroom here. This confirms the statement of this participant:

.....as I have said earlier, English is not our

language....I need ELF awareness to understand the concept...you see you cannot give what you don't have... when I get I better ELF awareness and what the whole concept is about then I can treat my own non- native 


\section{English spoken discourse as a worthwhile} model which my learners can learn from (ETR 3)

In a similar way, another participant added that

.....we are models for our learners....they look
up to us...they cannot use the language
wrongly and we also do same..... need ELF
awareness to be able to give corrective
feedbacks to my learners (ETR 5)

According to another participant, most tutors are more interested in developing some level of competency with regards to things like dealing with business transactions in a global context, how to interpret the English language and so on. That's why the skillset is useful, but the mindset is ideal. Teaching ELF does a very good job of linking theory to practice. This is an understated skill in the education sector.

Table 3: The benefits of ELF awareness

\begin{tabular}{lccc}
\hline Statement & Means & Std. Dev & rank \\
\hline $\begin{array}{l}\text { ELF awareness helps the CoE tutor of English to } \\
\text { accommodate learners of diverse L1 backgrounds }\end{array}$ & 2.68 & .95 & 4 \\
$\begin{array}{l}\text { ELF awareness helps the CoE tutor of English to } \\
\text { motivate the student teacher to learn the language }\end{array}$ & 2.76 & .63 & 3 rd \\
in a flexible atmosphere & & & \\
$\begin{array}{l}\text { ELF awareness equips the CoE tutor of English } \\
\text { with the skills needed to prepare the student }\end{array}$ & 3.60 & .88 & 1 st \\
teacher to teach basic school learners \\
$\begin{array}{l}\text { ELF awareness helps the CoE tutor of English to } \\
\text { select the appropriate instructional materials that }\end{array}$ \\
$\begin{array}{l}\text { fits their context } \\
\text { ELF awareness helps the CoE tutor of English to } \\
\text { adopt the right pedagogy to help the student } \\
\text { teacher-succeed }\end{array}$
\end{tabular}

From Table 3, it can be observed that the participants revealed that what they considered as most beneficial was "ELF awareness equips the CoE tutor of English with the skills needed to prepare the student teacher to teach basic school learners" $(\mathrm{M}=3.60, \mathrm{SD}=.88)$. This was followed by "ELF awareness helps the CoE tutor of English to select the appropriate instructional materials that fit their context" $(\mathrm{M}=2.96, \mathrm{SD}=.90)$.

ELF transcends the boundaries and allows for constant variation that is the result of the user's backgrounds, both linguistic and sociocultural, which influence their performance. language is the most essential tool for all human communication and learning; it is integral to every person's 
identity and it is one of the core elements of a culture. In education, language plays a crucial role because it is mainly through the interactions between the teacher and the learners, and amongst the learners themselves, that knowledge is produced and acquired in the teaching-learning process. It was also found that tutors used pragmatic strategies, such as repetition, questions, and comments to ensure that students comprehend what is being taught. It is worthy to state here that naturally, the students' language use situations are different from tutors. ELF is viewed in its strict sense: as a lingua franca among those who do not share a common language.

\section{Limitations of the study}

The study did not reflect the entire population of English tutors at all levels of education in the region. Only those teaching at the Colleges of Education were used in this study. The sample size used in this research also limits the generalizability of the findings. Another limitation of the study was that it was impossible to judge if the responses given by the participants were accurate or not. Although participants had been briefed about the purpose of the research, social desirability bias could possibly occur as the scales were self-report scales and were subject to participants' influence.

\section{Discussion}

In this study, we wanted to see to what extent English language tutors were aware of ELF in their English language classrooms. The findings suggest that there is a disconnection between what tutors believe, how they perceive the ELF construct and their teaching practices as revealed in previous studies (Bayyurt \& Sifakis, 2015a, 2015b). The findings indicated that participant tutors' awareness of the need to communicate in English was not restricted to native speaker communities. They also agreed that intercultural awareness was important for language users. These findings could be interpreted as the changing conceptualizations of English language and pedagogy among language tutors in various contexts. Nevertheless, their tendency to see the native speaker as a yardstick and the importance they attach to linguistic accuracy perhaps shows that a traditional EFL perspective is still preferred by English language tutors (Illés \& Csizér, 2015). However, how these tendencies relate to English language tutors' awareness of ELF depends on their local contexts. In different contexts, tutors may have different conceptualizations of ELF, and there can be a number of factors influencing their English language teaching practice, such as the presence of immigrants in their classrooms, linguistic and cultural differences between the immigrants and locals, attitudes of local students towards immigrants. Previous studies have documented that although tutors seem to welcome the idea of an ELF approach in their teaching practice, tutors do not know how to implement an ELF-aware approach to their 
language teaching materials since such materials hardly exist in the field (Bayyurt \& Sifakis, 2015a, 2015b; Kemaloğlu-Er \& Bayyurt, 2018; Sifakis \& Bayyurt, 2018). The results of the current study showed that tutors favour the idea that cultural diversity should be integrated into the English language teaching materials. In other words, they supported the idea that the cultures of both native speakers and nonnative speakers should be part of the English language classrooms (Bayyurt, 2006, 2017).

However, a great majority of the tutors in this study seem to be indecisive about the role of the inclusion of the non-standard varieties of English in their language teaching practice. In addition, the tutors, who participated in the study, had differing views on the role of grammatical accuracy in successful communication. While some of them agreed with the idea, others were not sure about what the role of grammatical accuracy is in successful communication (Bayyurt \& Sifakis, 2015a, 2015b). Moreover, they did not show a clear tendency towards supporting the idea that nonnative tutors should have a native-like competence-accent or native-like proficiency. Tutors highlighted the idea that intelligibility was more important than having a native-like accent especially in multilingual and multicultural contexts. Although these results support the findings of earlier studies (Bayyurt, 2017; Bayyurt \& Sifakis, 2015a, 2015b; Biricik-Deniz, 2017; Biricik-Deniz et al., 2016; Kemaloğlu-Er, 2017) on perceptions of ELF and its involvement in ELT, the intention of the researcher was not to generalize the results to the whole population of English language tutors in their contexts. Fostering awareness of the current diversification of English in teacher education can thus set the basis for acknowledging that WE and ELF can no longer be ignored in class: Rather than one single) variety (standard British English) or NS reference model, students should be presented with exemplifications of different accents, lingua-cultural varieties and contexts of use, going beyond static and monolithic representations of the language, as is still largely the case in ELT. In Kramsch's (2014) words, the purpose is not to abandon all standards pedagogic norms of language use as the goals of instruction. It is, rather, to strive to make our students into multilingual individuals, sensitive to linguistic, cultural and, above all, semiotic diversity, and willing to engage with difference, that is, to grapple with differences in social, cultural, political and religious worldviews.

\section{Pedagogical implications}

Based on the findings from the study, some pedagogical implications are drawn. English tutors should avail themselves of in-service training, workshops and seminars to abreast themselves with appropriate instructional methodologies for effective teaching. The Ministry of Education, through the Ghana Universities Council, mentoring universities and Colleges of Education 
should provide stimulus packages for teachers to acquire and develop effective teaching and learning materials for their lessons. Tutors should endear themselves to reading various write-ups and conversations of students to help them identify the errors they make and correct them. Tutors should seek ways of acquiring attitudes that can help them create a congenial atmosphere for teaching and learning as/ this is needed by students to understand what their teachers teach them. Tutors of English should ensure that classroom materials reflect the purpose for which English is learned. They should ensure that their teaching approach is geared towards motivating to be confident ELF speakers. Finally, they should create an atmosphere that will accommodate all learners irrespective of their L1 backgrounds.

\section{Conclusion}

Based on the finding of the study and subsequent discussions, the major conclusion is that, some tutors of English in the colleges were ELF aware practitioners even though they were unaware of their own practice. Tutors taught the way they did of the high- stake examinations their learners write at the end of the semester or training. It can be stated that tutors of the English Language in colleges of education should be made aware of the multifaceted reality of the English Language today. It is our hope that by raising awareness and linguistic diversity early in the course of a teacher's professional development, the practical relevance of ELF in tutors' perceptions of expertise will feature more prominently in their approach to language learning materials and tasks.

The study revealed that awareness of ELF is beneficial and therefore there is a need for it. It has also illuminated the level of knowledge of tutors on ELF.

\section{References:}

1. Adjaye, S.A. (2005). Ghanaian English Pronunciation. New York \& Ontario: The Edwin Mellen Press.

2. Anderson, J.A. (2006). Request forms in English in Ghana. Legon Journal of the Humanities, 17, 75-103.

3. Baker, W. (2015). Culture and identity through English as a lingua franca. Berlin \& Boston: de Gruyter Mouton.

4. Baker, W., \& Jenkins, J. (2015). Criticising ELF. Journal of English as a Lingua Franca, 4, 191- 198.

5. Bayyurt, Y. (2017). Non-native English language tutors' perceptions of "culture" in English language classrooms in a post-EFL era. In J. de Dios Martinez Agudo (Ed.), Native and Non-Native tutors in second language classrooms: Professional challenges and teacher education (pp. 139-159). Berlin: De Gruyter. 
6. Bayyurt, Y., \& Sifakis, N. C. (2015a). Developing an ELF-aware pedagogy: Insights from a self- education programme. New frontiers in teaching and learning English, 55-76.

7. Bayyurt, Y., \& Sifakis, N. C. (2015b). ELF-aware in-service teacher education: A transformative perspective. In H. Bowles, \& A. Cogo (Eds.), International perspectives on English as a Lingua Franca (pp. 117-135). Basingstoke, UK: Palgrave Macmillan.

8. Biricik-Deniz, E. (2017). A case study on ELF-aware pre-service language teacher education model: Theory into practice. (Unpublished $\mathrm{PhD}$ Thesis). Çukurova University, Adana, Turkey.

9. Biricik-Deniz, E., Özkan, Y., \& Bayyurt, Y. (2016). English as a Lingua Franca: Reflections on ELF-related issues by pre-service English language tutors in Turkey. The Reading Matrix, 16(2), 144161.

10. Blommaert J (2010). The sociolinguistics of globalization. Cambridge, UK: Cambridge University Press

11. Boadi, L.K.A. (1994) Linguistic barriers to communication in the modern world. Accra: Ghana Academy of Arts and Sciences.

12. Breiteneder, A. (2005). The naturalness of English as a European lingua franca: The case of the 'third person -s'. Vienna English Working Papers 14: 3- 26.

13. Canagarajah, S, (2013), Translingual practice: global Englishes and cosmopolitan relations. London: Routledge,

14. Canagarajah, S, (2011). Codemeshing in academic writing: identifying teachable strategies of translanguaging. Modern Language Journal, $95,401-417$

15. Canagarajah, A. S. (Ed.). (2005). Reclaiming the local in language policy and practice. Mahwah, NJ: Lawrence Erlbaum.

16. Cogo, A. \& Dewey, M. (2012). Analyzing English as a lingua franca: a corpus-driven investigation. London, New York: Continuum.

17. Crystal, D. (2003). English as a global language. Cambridge: Cambridge University Press

18. Dewey, M. (2006). English as a lingua franca: an empirical study of innovation in lexis and grammar. (Unpublished thesis). London: King's College.

19. Dzameshie, A.K. (2001) A cross-cultural comparison of requesting behaviour in Ewe, British English and Ghanaian English. Reading: University of Reading.

20. Ellis, R. (2010). Epilogue: A framework for investigating oral and written correctivefeedback. Studies in Second Language Acquisition, 32(2), 335-349 
21. Firth, A. (1996). The discursive accomplishment of normality: On conversation analysis and lingua franca English. Journal of Pragmatics, 26, 237-259

22. Giles, H., R.Y. Bourhis, P. Trudgill \& A. Lewis. (1974a). The imposed norm hypothesis: a validation. Quarterly Journal of Speech, 60. 405410.

23. House, J (1999) Misunderstanding in intercultural communication: interactions in English as a lingua franca and the myth of mutual intelligibility. In: Gnutzmann, C (ed.) Teaching and Learning English as a Global Language (pp. 73-89). Tübingen: Stauffenburg

24. Illés, É. \& Csizér, K. (2015). The disposition of Hungarian tutors of English towards the international use of the English language. In D. Holló \& K. Károly (Eds.), Inspirations in foreign language teaching: Studies in applied linguistics, language pedagogy and language teaching (pp. 170-183). London, UK: Pearson Education.

25. Jenkins, J. (2015). Repositioning English and multilingualism in English as a Lingua Franca. Englishes in Practice, 49-85.

26. Jenkins, J. (2015a). Global Englishes: A resource book for students, ( $3^{\text {rd }}$ ed.). Abingdon: Routledge.

27. Jenkins, J. (2007). English as a lingua franca: attitudes and identity. Oxford: Oxford University Press.

28. Jenkins, J. (2000). The phonology of English as an international language. Oxford: Oxford University Press.

29. Kalocsai, K. (2014). Communities of Practice and English as a Lingua Franca. Berlin: de Gruyter Mouton.

30. Keleve, M. (1995). Needs analysis for learners of English in Ghana in relation to language goals. ITL Review of Applied Linguistics, 1, 109110.

31. Kemaloğlu-Er, E. (2017). Integrating ELF-awareness into pre-service teacher education: Insights from theory and practical experience. (Unpublished thesis). Boğaziçi University, Istanbul, Turkey.

32. Kemaloğlu-Er, E., \& Bayyurt, Y. (2018). ELF-awareness in teaching and teacher education: Explicit and implicit ways of integrating ELF into the English language classroom. In N.C. Sifakis \& N. Tsantila (Eds.), English as a lingua franca for EFL contexts (pp. 159-174). Bristol: Multilingual Matters.

33. Kirkpatrick, A. (2006). Which model of English: Native-speaker, nativized, or lingua franca? In R. Rubdy \& M. Saraceni (Eds.), English in the world: Global rules, global roles. (pp. 71-83) London: Continuum Press. 
34. Kohn, K. (2015). A pedagogical space for ELF in the English classroom. In Y. Bayyurt and S. Akcan (Eds). Current perspectives on pedagogy for ELF (pp.51-67). Berlin: De Gruyter Mouton

35. Kramsch, C. (2014). Teaching foreign languages in an era of globalization. The Modern Language Journal, 98(1), 296-311.

36. Kramsch, C. (2009). Third culture and language education. In: Vivian Cook (ed.), Language teaching and learning, (pp.233-254). London: Continuum.

37. Leung, C. (2013). The "social" in English Language Teaching: abstracted norms versus situated enactments. Journal of English as a Lingua Franca, 2(2), 283-313.

38. Long, M. (1991). Focus on form: A design feature in language teaching methodology. In K. de Bot, R. Ginsberg, \& C. Kramsch (Eds.), Foreign language research in cross-cultural perspective, 39-52. Amsterdam: John Benjamins.

39. Lopriore, L. (2016). ELF in teacher education: A Way and Ways. Intercultural Communication. New Perspectives from ELF.

40. Lyster, R. \& Saito, K. (2010). Effects of oral feedback in SLA classroom research: A meta- analysis. Studies in Second Language Acquisition, 32, 265-302.

41. Mauranen, A. (2012). Exploring ELF: Academic English shaped by non-native speakers. Cambridge: Cambridge University Press.

42. Mauranen, A. \& Ranta, E. (eds.) (2009). English as a lingua franca: studies and findings. Newcastle upon Tyne: Cambridge Scholars.

43. McKay, S.L (2000). Teaching English as an International Language: Implications for Cultural Materials in the Classroom. TESOL journal, 9(4), 7-11.

44. Meierkord, C. (2002). Language stripped bare' or 'linguistic masala'? Culture in lingua franca communication. In K. Knapp \& C. Meierkord (Eds.), Lingua franca communication (pp. 109- 134). Frankfurt am Main: P. Lang.

45. Mortensen, J. (2013). Notes on English used as a lingua franca as an object of study. Journal of English as a Lingua Franca, 2, 25-46.

46. Pennycook, A. (2001). Critical applied linguistics: A critical introduction. Mahwah, NJ: Lawrence Erlbaum.

47. Quarcoo, E. (1994). The English language as a MODERN Ghanaian artefact. Journal of Black Studies, 24(3), 329-343.

48. Quirk, R., Greenbaum, S., Leech, G. \& Svartvik, J. (1972). A grammar of contemporary English. London: Longman.

49. Sackey, J. (1997). The English Language in Ghana: A historical perspective. In M.E. Kropp Dakubu (ed.) English in Ghana (pp.126139). Accra: GESA. 
50. Seidlhofer, B. (2012). Anglophone-centric attitudes and the globalization of English. Journal of English as a Lingua Franca, 1, 393-407.

51. Seidlhofer, B. (2011). Understanding English as a Lingua Franca. Oxford: Oxford University Press.

52. Sey, K.A. (1973). Ghanaian English. London: Macmillan.

53. Sifakis, N. (2009). Challenges in teaching ELF in the periphery: The Greek context. ELT Journal, 63(3), 230-237.

54. Sifakis, N. (2004). Teaching EIL- teaching international or intercultural English: What teachers should know. System, 32(2), $237-$ 250.

55. Sifakis, N., \& Bayyurt, Y. (2018). ELF-aware teaching, learning and teacher development. In J. Jenkins, W. Baker, \& M. Dewey (Eds.), Handbook of English as a Lingua Franca (pp. 456-467). London: Routledge.

56. Sifakis, N., Lytra, V. \& Fay, R. (2012). Curricular discourses and English as a Lingua Franca in the Greek state school context. Paper presented at the 5th ELF Conference, Boğaziçi University, Istanbul.

57. Song, H. (2013). Deconstruction of cultural dominance in Korean EFL textbooks. Intercultural Education, 24(4), 382-390.

58. Suzuki, A. (2011). Introducing diversity of English into ELT: student tutors' responses. ELT Journal, 65(2), 145-153.

59. Swain, M. (2006). Languaging, agency and collaboration in advanced second language learning. In H. Byrnes (Ed.), Advanced language learning: The contributions of Halliday and Vygotsky (pp. 95-108). London, England: Continuum.

60. Wall, D. (2005). The impact of high-stakes examinations on classroom teaching: A case study using insights from testing and innovation theory. Cambridge: Cambridge University Press.

61. Wang, W. (2015). Teaching English as an international language in China: Investigating university teachers' and students' attitudes towards China English. System, 53, 60- 72.

62. Widdowson, H.G. (2003). Defining Issues in English Language Teaching. Oxford: Oxford University Press. 